\title{
Erratum to: Oxidative stress in the lung of mice exposed to cigarette smoke either early in life or in adulthood
}

\author{
Rosanna T. Micale $\cdot$ Sebastiano La Maestra $\cdot$ Angela Di Pietro $\cdot$ Giuseppa Visalli \\ Barbara Baluce $\cdot$ Roumen Balansky $\cdot$ Vernon E. Steele $\cdot$ Silvio De Flora
}

Published online: 21 March 2013

(c) Springer-Verlag Berlin Heidelberg 2013

\section{Erratum to: Arch Toxicol}

DOI 10.1007/s00204-012-0993-1

In the original publication, the author names, Sebastiano La Maestra and Angela Di Pietro, were erroneously abbreviated as S. L. Maestra and A. D. Pietro.

The correct abbreviations should read as S. La Maestra and A. Di Pietro.

The online version of the original article can be found under doi:10.1007/s00204-012-0993-1.

R. T. Micale - S. La Maestra · R. Balansky · S. De Flora $(\square)$ Department of Health Sciences, University of Genoa,

Via A. Pastore 1, 16132 Genoa, Italy

e-mail: sdf@unige.it

R. T. Micale

e-mail: rosannamicale@yahoo.it

S. La Maestra

e-mail: lamaestra78@yahoo.it

R. Balansky

e-mail: rubalansky@sbaloncology.bg

\footnotetext{
A. Di Pietro · G. Visalli - B. Baluce

Department of Hygiene, Public Health and Preventive Medicine, University of Messina, Via Consolare Valeria, 98125 Messina, Italy

e-mail: adipietr@unime.it

G. Visalli

e-mail: giusyvisally@yahoo.it
}

B. Baluce

e-mail: barbarabaluce@yahoo.it

B. Baluce

Cell Factory, Department of Regenerative Medicine,

Fondation IRCCS Ca' Granda, Ospedale Maggiore Policlinico,

Via Francesco Sforza 35, 20122 Milan, Italy

R. Balansky

National Center of Oncology, Str. Plovdisko pole 6,

Sofia 1756, Bulgaria

V. E. Steele

National Cancer Institute, 6130 Executive Blvd,

Room 2118, Rockville, MD 20852, USA

e-mail: steelev@mail.nih.gov 